\title{
Webové služby pro poskytování návrhových srážek
}

\section{MARTIN LANDA, PETR KAVKA, LUDĚK STROUHAL, JIŘí CAJTHAML}

Klíčová slova: hydrologické modelování - návrhové srážky - GIS - webové služby - publikace

\section{SOUHRN}

V rámci využití nástrojů geografických informačních systémů (GIS) v hydrologickém modelování se do popředí dostávají tzv. webové služby, které uživatelům umožňují rychle a efektivně získat potřebná vstupní data pro vlastní modelování. Z hlediska jednoho z klíčových vstupů - návrhových deštů - je tento deficit v rámci ČR značný. Zde popisovaný príspěvek představuje vznikající portál pro poskytování srážkových dat, na němž jsou provozovány dva typy služeb. První z nich má za cíl poskytovat náhled na mapové vrstvy N-letých maximálních denních úhrnů za účelem tvorby mapových kompozic. Druhá služba již poskytuje výpočetní nástroje, které může uživatel vzdáleně využívat.

Webové služby jsou poskytovány podle standardů Open Geospatial Consorcium (OGC). První z výše zmíněných služeb je postavena na standardu Web Map Service (WMS), druhá poté na Web Processing Service (WPS).

Výpočetní služba na bázi WPS poskytuje dvě základní sady procesů (dále v textu označované jako "nástroje"). První část nástrojů vyčísluje na základě vstupních bodových či polygonových dat a délky srážky hodnoty úhrnů návrhových srážek za zvolenou dobu opakování. Druhá část nástrojů již pracuje s časovou distribucí srážek odvozenou pro pevně definovanou dobu srážky 6 hodin a kromě úhrnu tak nově poskytuje i teoretické tvary návrhových srážek a jejich pravděpodobnost výskytu.

Př́spěvek dále představuje moderní publikační platformu Gisquick, která umožňuje snadnou tvorbu vizuální interaktivní webové mapové aplikace. Zde je využita pro publikaci typizovaného výpočtu návrhových srážek na povodích 4. řádu s využitím WPS nástrojü.

\section{ÚVOD}

Získat rychle a efektivně vstupní data je jedním z klíčových momentů pro využití geografických informačních systémů (GIS) v hydrologickém modelování. Proto se do popředí dostávají moderní technologie založené na principu tzv. webových služeb či aplikací. Jeden z príkladů takovéto webové aplikace může být model Bilan [1]. Tento příspěvek přestavuje vznikající mapový portál RAIN (rain.fsv.cvut.cz) poskytující webové služby a aplikace o krátkodobých deštích návrhových srážkách. V rámci portálu jsou provozovány v současnosti dva typy webových služeb. První z nich, OGC WMS - Web Map Service, má za cíl poskytovat náhled na mapové vrstvy N-letých maximálních denních úhrnů za účelem tvorby mapových kompozic. Druhým typem služby je OGC WPS - Web Processing Service poskytující výpočetní nástroje, které může uživatel vzdáleně využívat. Cílem těchto služeb je poskytnout uživateli geograficky lokalizovaná srážková data a současně i nástroje pro jejich zpracování.

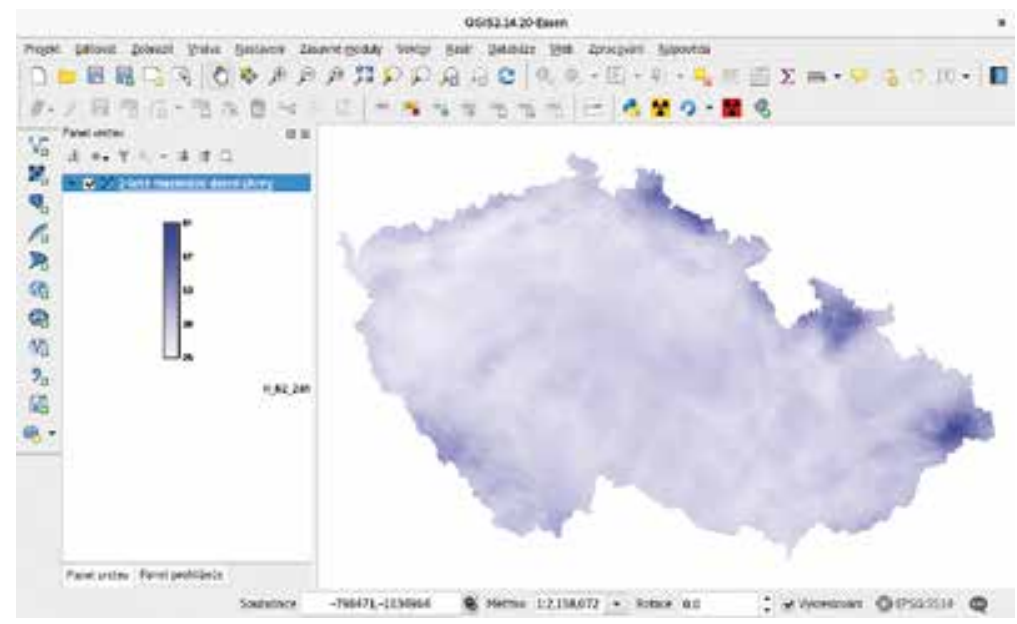

Obr. 1. WMS vrstva 2letých maximálních denních úhrnů zobrazená v programu QGIS Fig. 1. WMS layer of maximum daily rainfall depths with return period of 2 years displayed in QGIS

Provozované webové služby jsou po technologické stránce implementovány na bázi open source komponent, konkrétně jde o operační systém Debian, mapový server MapServer, WPS framework PyWPS a GIS analytický nástroj GRASS GIS. Autoři zvolili open source komponenty především s cílem dlouhodobé udržitelnosti řešení nezávislého na externím dodavateli. Z pohledu uživatele jsou mapové podklady a výpočetní služby zprístupněny v libovolném softwaru, který podporuje služby OGC WMS a WPS.

\section{Datová základna provozovaných webových služeb}

Základem poskytovaných dat jsou předzpracované rastrové vrstvy. Jedním typem vrstev jsou denní úhrny odvozené na základě bodových hodnot publikovaných Šamajem [2]. Jedná se o rastrová data v prostorovém rozlišení 1 km, hodnoty byly vyhodnoceny pro doby opakování 2 až 100 let. Metodu plošné interpolace bodových hodnot na základě vícerozměrné regrese podrobněji popisuje Kavka [3].

Druhým typem vrstev jsou odhady šestihodinových úhrnů odvozených na základě desetileté řady adjustovaných radarových dat a pozemních měření. Jedná se sice o aktuálnější datový podklad (2002-2011), nicméně pro frekvenční analýzu dostupná desetiletá řada pozorování s sebou nese nejistoty zejména v oblasti úhrnů dlouhých dob opakování. Podrobný popis odvození těchto vrstev je teprve připravován k článku Müllera a kol. viz [5]. Tato vstupní data 


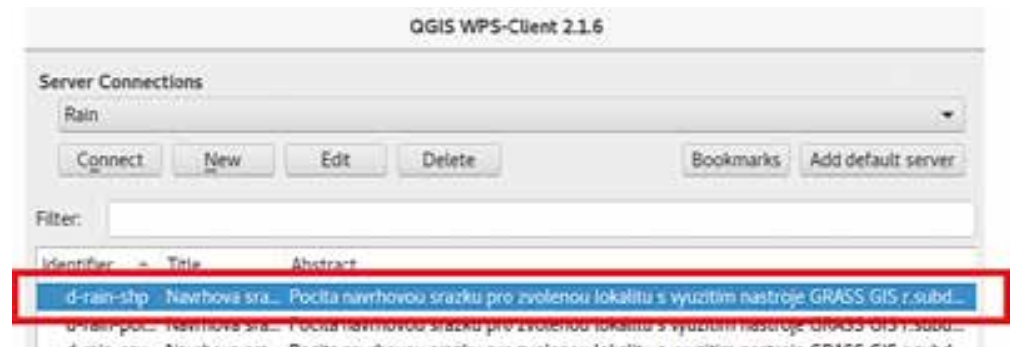

d-rain-csi Navihova sa. Pocha navithovou srazku pro zolenou lokalitu s wuzzitim nastroje GRASS GIS r subd.

Obr. 2. Výběr WPS nástroje d-rain-shp v programu QGIS

Fig. 2. Choosing d-rain-shp WPS tool in QGIS

obsahují kromě informace o hodnotě šestihodinového úhrnu srážky i pravděpodobnosti výskytu šesti typizovaných časových průběhů srážky v závislosti na zvolené lokalitě v rámci ČR.

\section{WEBOVÉ SLUŽBY}

\section{Web Map Service}

Cílem služby Web Map Service (WMS) je poskytnout náhled rastrových vrstev N-letých maximálních denních úhrnů jednoduchou a snadno dostupnou formou. WMS je nejrozšířenějším typem webových služeb, proto nechybí ani $\checkmark$ predstavovaném portálu.

$\checkmark$ rámci této služby jsou dostupné náhledy N-letých maximálních denních úhrnů v prostorovém rozlišení $1 \mathrm{~km}$. Podporovanými souřadnicovými systémy jsou S-JTSK (EPSG:5514), UTM 33N (EPSG:32633) a WGS-84 (EPSG:4326). Konkrétně se jedná o následující vrstvy (obr. 1):

— 2leté maximální denní úhrny (H_N2_24h),

- 5leté maximální denní úhrny (H_N5_24h),

— 10leté maximální denní úhrny (H_N10_24h),

— 20leté maximální denní úhrny (H_N20_24h),

— 50leté maximální denní úhrny (H_N50_24h),

— 100leté maximální denní úhrny (H_N100_24h).

Služba je dostupná na adrese https://rain1.fsv.cvut.cz/services/wms, podrobnější informace je možné získat na stránce portálu.

\section{Web Processing Service}

Kromě dobře známé a rozšiřené služby WMS je v rámci portálu poskytována i pro uživatele zajímavější služba Web Processing Service (WPS), která umožňuje výpočet hodnot úhrnů návrhových srážek podle zadaných vstupních parametrů. Jelikož jsou veškeré výpočty prováděny na vzdáleném serveru, nepotřebuje uživatel, kromě WPS klienta, instalovat žádný další softwarový nástroj.

$\checkmark$ rámci této služby může uživatel přistupovat $k$ celkem pěti různým nástrojům. První tři (d-rain-shp, d-rain-csv a d-rain-point) vrací hodnoty úhrnů návrhových srážek v mm pro uživatelem zadaná vektorová polygonová či bodová data, dobu opakování a délku srážky. Hodnota úhrnu návrhové srážky zvolené délky trvání je počitána na výpočetním serveru nástrojem r.subdayprecip. design založeném na redukci denních úhrnů podle známého vztahu a koeficientů metodiky [4]. Úhrny jsou získány pomocí zonální statistiky nad rastrem denních úhrnů s prostorovým rozlišením 1 km, jehož odvození popisuje Kavka a kol. [3]. Tento nástroj tedy uživatelům, kteří používali například ručně interpolované a pro ČR tabelované denní hodnoty a na jejich základě pak redukční metodou určovali srážku zvolené délky, významně usnadňuje její získání.

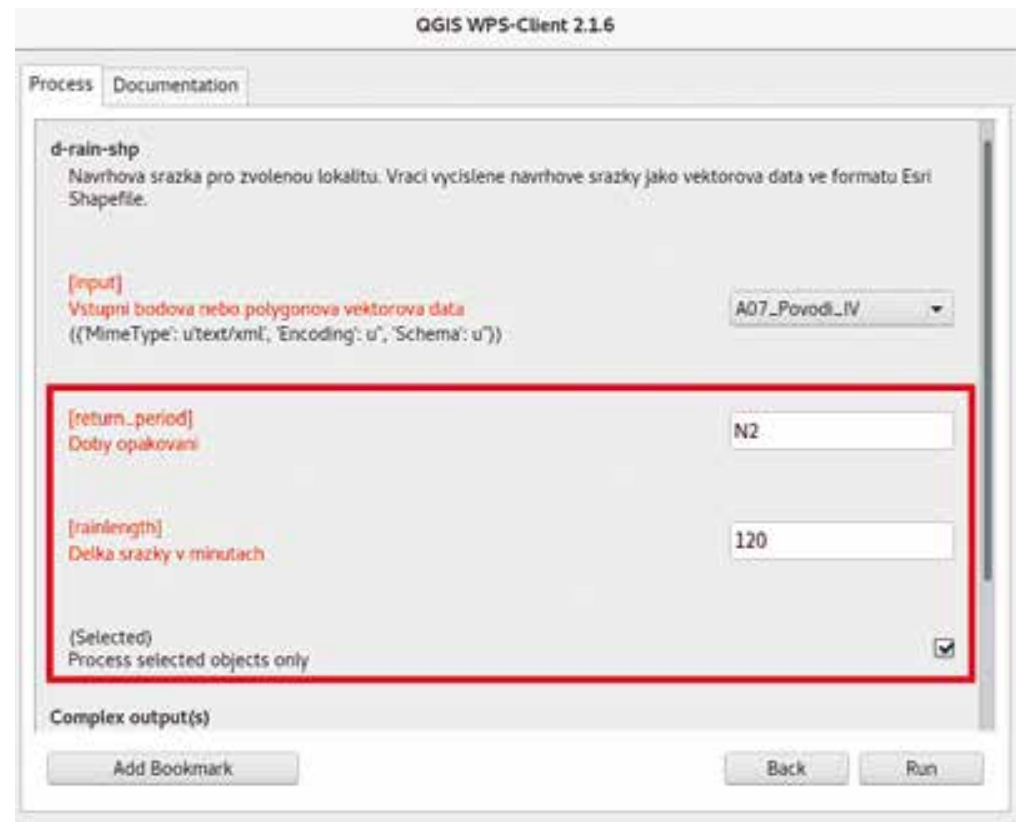

Obr. 3. Spuštení WPS nástroje d-rain-shp pro dobu opakování 2 roky a délkou srážky $120 \mathrm{~min}$

Fig. 3. Launching d-rain-shp WPS tool with input parameters of return period of 2 years and rain length of $120 \mathrm{~min}$

Vzhledem k tomu, že byly N-leté úhrny odvozeny jako bodové hodnoty, mají služby definovány plošné omezení na vstupní data. Pro polygony s výměrou nad 20 km² vrací nástroje chybovou hodnotu úhrnu návrhové srážky -1.

Výše zmiňované tři nástroje se liši pouze typem výstupu. Zatímco nástroj d-rain-shp vrací výstupní data v GIS formátu Esri Shapefile, d-rain-csv poskytuje vypočítané úhrny návrhových srážek v textovém formátu Comma Seperated Values (CSV), která si může uživatel otevřít $v$ běžném tabulkovém procesoru. Poslední uvedený nástroj d-rain-point vyčíslí hodnotu návrhové srážky pouze pro jeden zadaný bod. Tato služba je využívána v navazující webové aplikaci, viz kapitola Webová aplikace pro bodový výpočet návrhové srážky. Následuje př́klad výstupu nástroje d-rain-csv s délkou srážky 3 hodiny (T180) a dobou opakování 2 a 5 let (N2 a N5). První sloupec obsahuje jednoznačné identifikátory vstupních vektorových prvků.

\section{ID, H_N2T180_mm, H_N5T180_mm}

$109030830,25.7,39.0$

$109030850,25.0,38.1$

$109030810,25.4,38.6$

Druhá skupina nástrojů je fixována na délku trvání srážky 6 hodin. Tato služba vrací uživateli šestihodinové úhrny včetně jejich časového průběhu podle jednoho až šesti typických tvarů návrhových srážek. Kromě jednotlivých typů časového průběhu také vrací pravděpodobnost jejich výskytu. Typické průběhy a jejich pravděpodobnosti výskytu jsou označovány písmeny $A$ až F. Hodnoty šestihodinových úhrnů byly odvozeny frekvenční analýzou radarových srážkových dat. Použité metody detailněji popisuje Müller [5].

První z těchto nástrojů, d-rain6h-timedist, vyčíslí průběhy šestihodinových návrhových srážek včetně jejich pravděpodobnosti výskytu na základě vstupních polygonových či bodových dat zadaných uživatelem. Úhrn srážky je vyčíslen na základě zonální statistiky nad rastrem šestihodinových úhrnů. Úhrn je dále distribuován do časového průběhu pomocí bezrozměrných typizovaných distribučních křivek. Pravděpodobnost výskytu daného typu průběhu srážky 


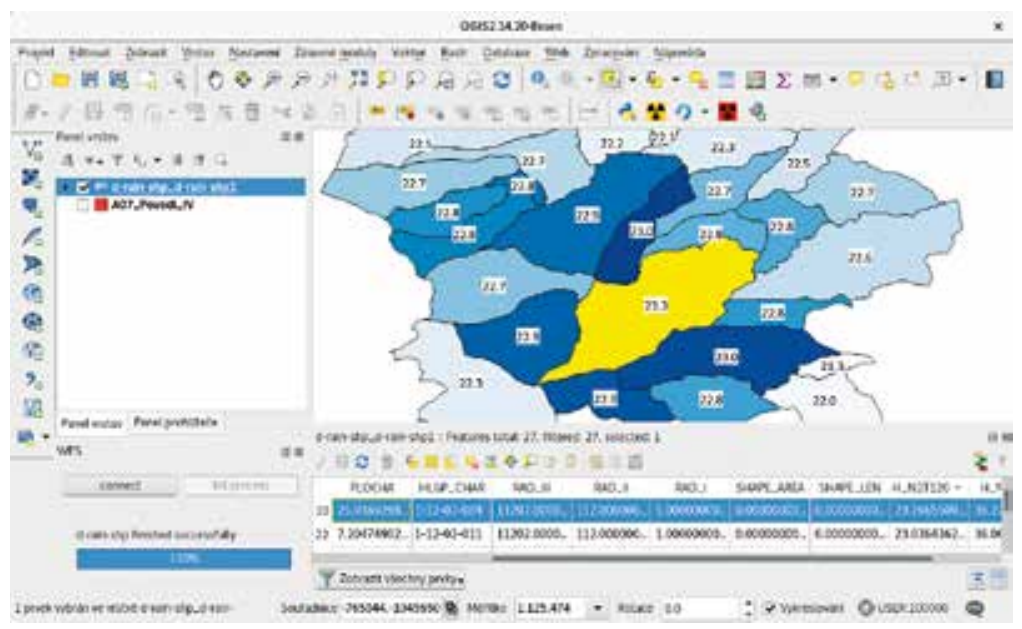

Obr. 4. Př́klad vizualizace hodnot úhrnů návrhových srážek vypočtených nástrojem d-rain-shp v prostředí programu QGIS

Fig. 4. Visualision of design rainfall depths computed by d-rain-shp tool in QGIS environment

je odvozena taktéž zonální statistikou nad rastry relativních četností v prostorovém rozlišení $1 \mathrm{~km}$. Druhý nástroj totalrain6h-timedist vrací průběhy šestihodinových návrhových srážek pro uživatelem prímo zadanou hodnotu úhrnu návrhové srážky. Tento nástroj umožňuje uživateli zadat jiným způsobem získaný úhrn šestihodinové srážky, např́klad na základě dat získaných od ČHMú. Časový průběh srážky je odvozen stejným způsobem jako v prípadě předchozího nástroje. Pravděpodobnost výskytu jednotlivých typů průběhu srážky neposkytuje. Oba nástroje vrací výsledky v jednoduchém textovém formátu CSV. Př́klad výstupu nástroje d-rain6h-timedist pro dobu opakování 2 a 5 let (N2 a N5) s tvarem návrhové srážky typu A (viz [5]):

ID, CAS_min, H_N2typA_mm, H_N5typA_mm, P_N2typA_\%, P_N5typA_\% $109030830,0,1,16.0,14.3$

$109030830,5,0.006,0.008$

$109030830,10,0.009,0.013$

\section{$109030830,355,0.028,0.038$ \\ $109030830,360,0.016,0.021$ \\ $109030850,0,1,13.3,11.8$}

$109030850,5,0.006,0.008$

$109030850,10,0.009,0.012$

První sloupec (v našem případě s názvem ID) je jednoznačný identifikátor vybraný uživatelem z atributů vyskytujících se v odesílaném vektorovém GIS souboru (typicky např. ve formátu Esri Shapefile), který umožňuje přiřadit vypočítané hodnoty pưvodním vektorovým prvkưm. Název klíčového atributu je zadán jako parametr WPS nástroje keycolumn.

První datový rádek pro každý prvek (zvýrazněn zelenou barvou) již obsahuje rozepsané pravděpodobnosti výskytu daného tvaru návrhové srážky, ve výše uvedeném př́kladu jde o sloupce P_N2typA_\% a P_N5typA_\%. Na dalších rádcích (žlutá barva) jsou poté rozepsány $\vee$ kroku po 5 minutách úhrny návrhových srážek pro danou dobu opakování a typ tvaru srážky, v našem prípadě jde o sloupce CAS_min, H_N2typA_mm a H_N5typA_mm.

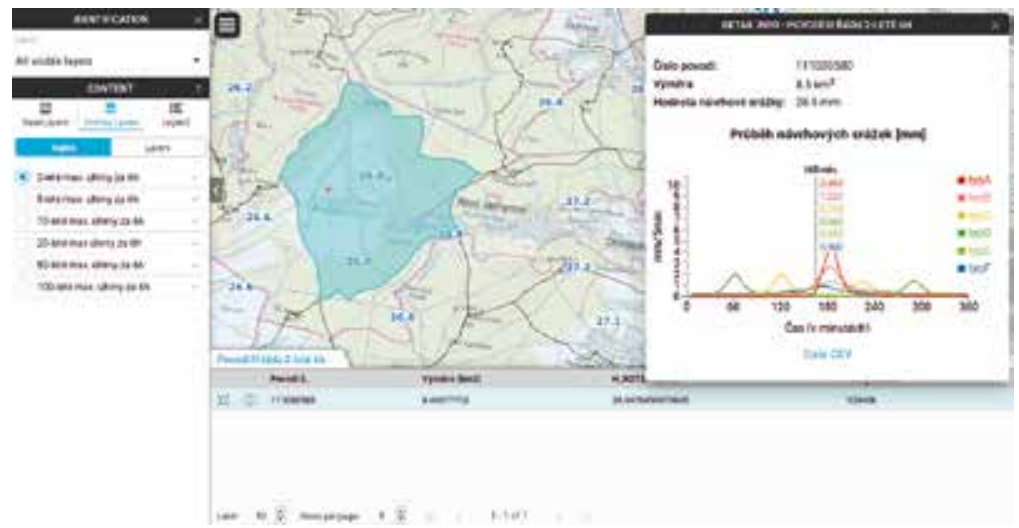

Obr. 5. Zobrazení teoretických průběhů návrhových srážek pro dané povodí na webové platformě Gisquick

Fig. 5. Visualisation of typical temporal distribution of a design rainfall for given basin in Gisquick web publishing platform

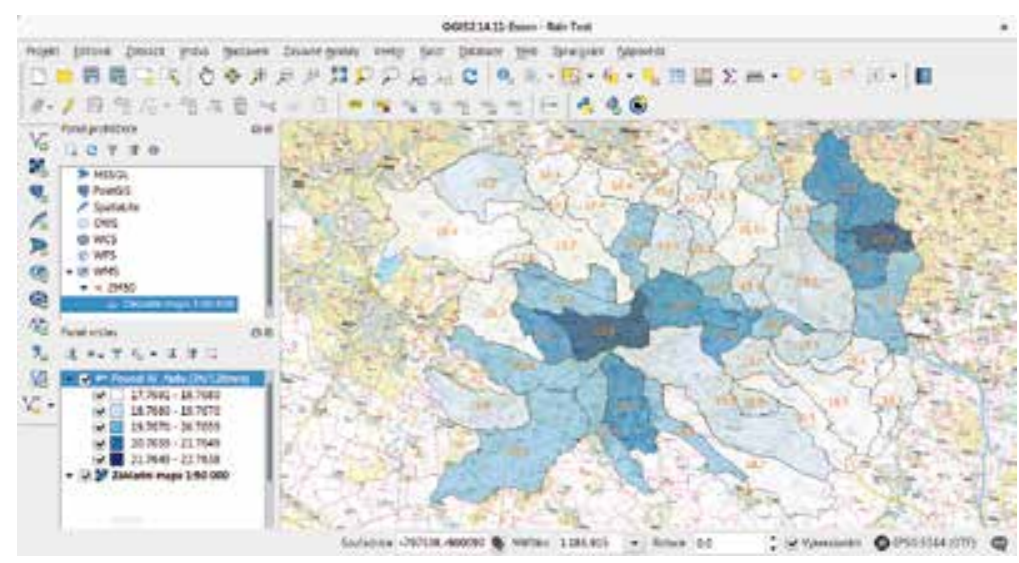

Obr. 6. Př́prava mapového projektu v prostředí programu QGIS

Fig. 6. Map project preparation in QGIS

\section{Využití webových služeb v rámci (Q)GIS}

Výpočetní webové služby typu WPS Ize volat prímo z bežného webového prohlížeče, nicméně pro drtivou většinu uživatelư je přístupnější použití specializované aplikace, tzv. WPS klienta. V textu je prezentováno použití WPS služby v dobře známém open source GIS nástroji QGIS, který je volně dostupný, podporuje službu OGC WPS, a tudiž je i ideální pro využití širokou veřejností. Po instalaci WPS klienta do prostředí QGIS mủžeme volně přistoupit k výše zmíněným nástrojům, jako je např. d-rain-shp, viz obr. 2 a 3. Dále byla služba WPS testována v rozšî̌reném softwaru Esri ArcGIS, ten ale bohužel standard OGC WPS nativně nepodporuje a softwary třetích stran v podobě WPS klienta nefungují zcela bez problému.

Výsledek výpočtu se poté zobrazí prímo v mapovém okně QGISu, viz obr. 4.

Služba je dostupná na adrese https://rain1.fsv.cvut.cz/services/wps. Podrobný návod volání WPS nástroje z prostředí desktopového programu QGIS je dostupný v dokumentaci portálu'. 
Publish in Gisqulck

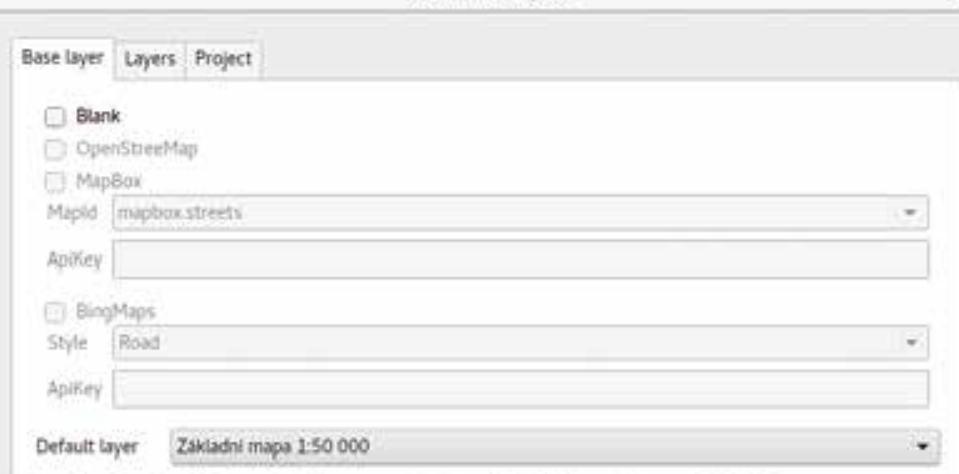

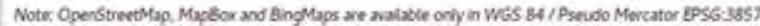

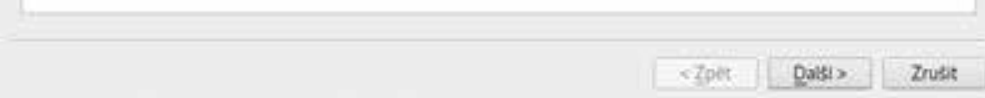

Obr. 7. Publikace mapového projektu pomocí nástroje Gisquick plugin

Fig. 7. Map project publication using Gisquick plugin

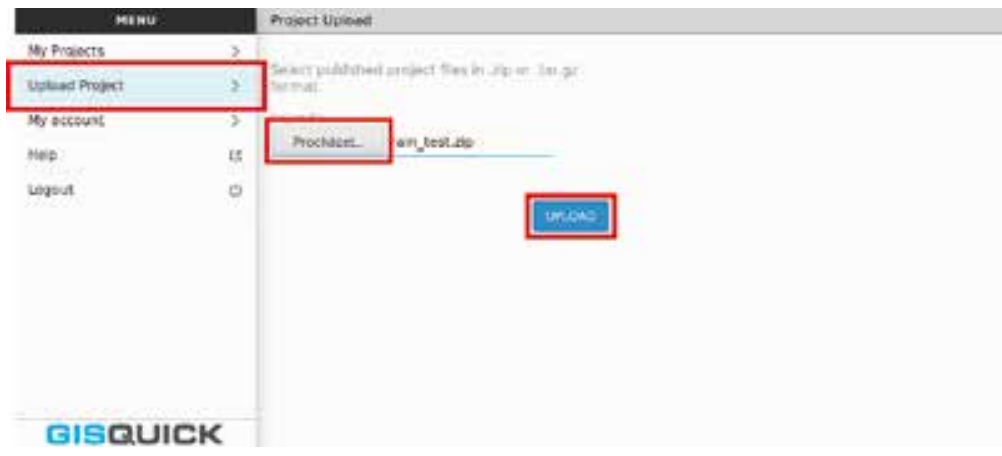

Obr. 8. Nahrání mapového projektu ve formátu ZIP do webového prostředí Gisquick Fig. 8. Uploading map project in ZIP format in web Gisquick interface

\section{WEBOVÉ APLIKACE A PUBLIKOVÁNÍ DAT}

Na webové služby OGC WMS a WPS navazují v rámci portálu provozované webové aplikace. Konkrétně se jedná o jednoduchou webovou aplikaci pro bodový odečet úhrnu návrhové srážky a komplexní webovou platformu umožňující snadnou publikaci výsledků výpočtu návrhových srážek v podobě interak tivní webové mapové aplikace. Podobně jako v prípadě webových služeb jsou i webové aplikace postaveny na bázi open source softwarových komponent, a to predevším projektu Gisquick, který byl pro účely prezentovaného portálu upraven, konkrétně doplněn o možnost zobrazení tzv. info panelu včetně interaktivního grafu [6]. V duchu open source vývoje byly tyto úpravy zpětně začleněny do projektu Gisquick, mohou z nich čerpat tudiž i jeho dalši uživatelé. Podrobné informace jsou k dispozici v dokumentaci na adrese https://rain1.fsv.cvut.cz/docs.

\section{Webová platforma Gisquick pro publikování výpočtu návrhové srážky}

Z původního záměru prezentovat úhrny návrhových srážek pro typizovaná povodí 4. rádu včetně jejich teoretických tvarů vznikla široce rozkročená webová platforma umožňující relativně snadnou publikaci vlastních

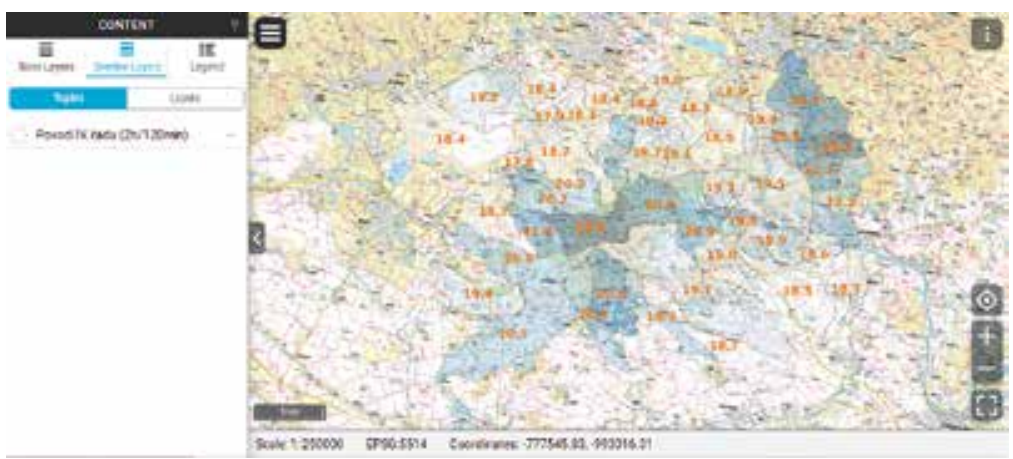

Obr. 9. Př́klad vlastní publikované webové aplikace zobrazené v běžném webovém prohližeči

Fig. 9. Example of sample published web application shown in common web browser

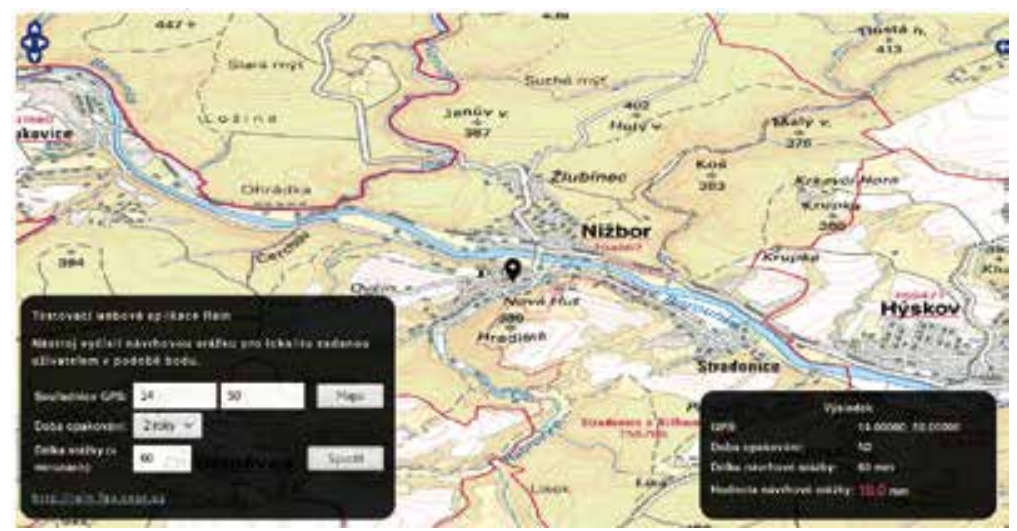

Obr. 10. Ukázka výpočtu návrhové srážky pro zadaný bod ve webové aplikaci Fig. 10. Calculation of the design rainfall depth for given location in the web application

dat. Nicméně základem zůstává ukázková aplikace, která zobrazuje typizovanou vrstvu povodí 4. rádu s vyčíslenými úhrny návrhových srážek v tématech podle doby opakování $(2,5,10,20,50$ a 100 let) odvozenými pro pevně definovanou dobu srážky 6 hodin. Pomocí vestavěného nástroje identify Ize pro vybrané povodí zobrazit grafickou interpretaci průběhu teoretických tvarů, viz obr. 5. Zároveň je možné získat výše uvedené rozdělení šestihodinového úhrnu do přílušných tvarů včetně pravděpodobnosti jejich výskytu ve formátu CSV (odpovídající funkcionalitou webovému nástroji d-rain6h-timedist). Aplikace je dostupná na adrese https://rain1.fsv.cvut.cz/webapp/gisquick.

\section{PROCES TVORBY VLASTNII WEBOVÉ APLIKACE}

Zajímavou funkcionalitou webové platformy Gisquick je možnost publikovat vlastní mapové projekty. Každý uživatel si může vytvořit webovou aplikaci podobnou té, která byla představena v úvodu této kapitoly. Proces tvorby mapového projektu od registrace do systému až po jeho publikování je podrobně popsán v dokumentaci (https://rain1.fsv.cvut.cz/docs). V tomto textu budou zmíněny pouze podstatné body publikačního procesu. Publikace vlastních projektů vyžaduje registraci uživatelského účtu v platformě Gisquick ve formě vyplnění jednoduchého formuláře a potvrzení registrace e-mailovou komunikací. Mapový projekt musí být nejprve připraven na počítači uživatele, a to v prostředí open source nástroje QGIS, viz obr. 6.

$\checkmark$ druhém kroku je tento projekt publikován specializovaným nástrojem "Gisquick plugin" (viz obr. 7) do formy ZIP souboru, který muže být poté přes webové rozhraní Gisquicku nahrán na publikační server, viz obr. 8.

Po nahrání projektu do webového prostředí Gisquick je automaticky vytvořena webová mapová aplikace, proces publikace je dokončen. Výsledek je znázorněn na obr. 9. 


\section{Webová aplikace pro bodový výpočet návrhové srážky}

Tato aplikace vznikla jako pilotní ukázka integrace nabízených WPS nástrojů do běžné webové mapové aplikace. $V$ jednoduchém prostředí zajištovaném knihovnou OpenLayers je možné volat nástroj d-rain-point (viz kapitola Web Processing Service), a tak interaktivně pro daný bod odečitat při zadané hodnotě doby opakování a délky srážky hodnotu úhrnu návrhové srážky v mm. Polohu bodu Ize pritom zadat bud' interaktivně kliknutím, či posunem bodu $\checkmark$ mapě, nebo prímým zadáním souřadnic zeměpisné délky a šiřky do webového formuláre, viz obr. 10. Aplikace je dostupná na adrese https://rain1.fsv.cvut.cz/ webapp/d-rain-point.

\section{ZÁVĚR}

Příspěvek prezentuje mapový portál rain.fsv.cvut.cz poskytující webové služby a aplikace pro odvození krátkodobých deštư - návrhových srážek. Vznik tohoto portálu umožňuje uživatelům získat návrhové srážky pro kteroukoliv lokalitu v rámci ČR efektivní a moderní formou. Doplňuje tak obtížně získatelný zdroj dat pro hydrologické modelování. Veřejnosti jsou nabídnuty nejen náhledy rastrových vrstev N-letých maximálních denních úhrnů, ale především specializované výpočetní nástroje pro určení úhrnů návrhových srážek a jejich typických časových průběhů pro geografická vstupní data zadaná uživatelem. Vzhledem k tomu, že jsou tyto výpočetní nástroje poskytovány jako webová služba (WPS), nekladou na straně uživatele omezení na použitý software, platformu či zařízení. K jejich konzumaci stačí softwarový nástroj podporující službu WPS.

Z tohoto pohledu je portál inovativní, především v oblasti hydrologického modelování, kde nejsou podobně navržené webové služby běžné. Na webové služby navazuje samostatná webová aplikace pro výpočet úhrnu návrhové srážky pro zadaný bod a webová platforma Gisquick umožňující vyčíslené úhrny návrhových srážek prezentovat atraktivním způsobem ve formě webové mapové aplikace. Portál tak svým uživatelům nabízí ucelenou škálu webových služeb a prezentační možnosti online.

\section{Poznámky}

1. https://rain1.fsv.cvut.cz/docs/projekt.html\#vypocet-uhrnu-navrhovych-srazek

\section{Poděkování}

Tento príspěvek vznikl v rámci řešeníprojektu NAZV QJ1520265 Vliv variability krátkodobých srážek a následného odtoku v malých povodích České republiky na hospodaření s vodou v krajině.

\section{Literatura}

[1] VIZINA, A., HORÁČEK, S., HANEL, M. a KAŠPÁREK, L. Nové možnosti modelu Bilan. VTEI, 2015, roč. 57, Č. 4-5, s. 7-10. ISSN 0322-8916.

[2] ŠAMAJ, F., VALOVIČ, Š. a BRÁZDIL, R. Denné úhrny zrážok s mimoriadnou výdatnostou v ČSSR v období 1901-1980. In: ŠAMAJ, F. ed. Zborník prác Slovenského hydrometeorologického ústavu. Bratislava: ALFA, 1985, s. 9.

[3] KAVKA, P., STROUHAL, L., LANDA, M. a DAVID, V. Nástroj pro odvození návrhových srážkových úhrnů na území ČR. Vodní hospodárství, 2016, roč. 66, č. 8, s. 9-15. ISSN 1211-0760.

[4] HRÁDEK, F. a KOVÁŘ, P. Výpočet náhradních intenzit přivalových deštư. Vodni hospodářství, 1994, roč. 11, s. 49. ISSN 1211-0760.

[5] MÜLLER, M., KAŠPAR, M., and BLIŽŇÁKK, V. Analysis of rainfall time structures on a scale of hours. 2017. Manuscript submitted for publication in Atmos. Res., under review.

[6] LANDA, M., KAVKA, P., STROUHAL, L., et al. Building A Complete Free and Open Source GIS Infrastructure for Hydrological Computing and Data Publication using GIS.lab and Gisquick Platforms. 2017. Int. Arch. Photogramm. Remote Sens. Spatial Inf. Sci., XLII-4/W2, p. 101-105. Dostupné z: https://doi.org/10.5194/isprs-archives-XLII-4-W2-101-2017, 2017.

\section{Autoři}

Ing. Martin Landa, Ph.D.

凶martin.landa@fsv.cvut.cz

Ing. Petr Kavka, Ph.D.

凶petr.kavka@fsv.cvut.cz

Ing. Luděk Strouhal, Ph.D.

凶ludek.strouhal@fsv.cvut.cz

doc. Ing. Jiři Cajthaml, Ph.D.

凶jiri.cajthaml@fsv.cvut.cz

České vysoké učení technické v Praze, Fakulta stavební

Příspěvek prošel lektorským řízením. 


\section{WEB SERVICES FOR THE PROVISION OF DESIGN RAINFALL}

LANDA, M.; KAVKA, P.; STROUHAL, L.; CAJTHAML, J.

CTU in Prague, Faculty of Civil Engineering

Keywords: hydrological modelling - design rainfalls -

GIS - web services - publishing

In the field of GIS support for hydrological modelling there has been distinct evolution towards so called web services, which enable the users to obtain necessary input data for modelling in a fast and effective way. With respect to design rainfall data - one of the key component - the deficit has been considerable. This article describes an upcoming portal operating two types of web services providing rainfall data. First service provides the view-only raster layers of maximum daily precipitation with several levels of return period for the use in the map compositions. The second service offers several processing services which can be remotely utilized by the user.

The web services are provided according to the Open Geospatial Consorcium (OGC) standards. First service is based on the Web Map Service (WMS) standard, the other on the Web Processing Service (WPS) standard.

The processing service based on WPS provides two basic sets of tools. First toolset takes the point or polygon data as an input and for the specified region of Czech republic calculates the design rainfall depths for an event of required duration and return period. The second toolset additionally considers the temporal distribution of the events, but is fixed to the duration of six hours. Beside the rainfall depths the tools return up to six typical temporal patterns and their occurrence probability for the specified region and return period.

Next this article presents a modern publishing platform Gisquick, which enables fast creation of an visual interactive web map application. Here it is utilized for publishing the typical project of design rainfalls derivation for the small catchments with the use of presented WPS tools. 